\title{
14. UNDERSTANDINGS OF CAREER GUIDANCE QUALITY IN NORWEGIAN SCHOOLS
}

\begin{abstract}
In this chapter I argue that there are many different ways to understand quality in career guidance in Norwegian schools. I discuss different understandings of quality in this context, using the conceptualisation of career guidance informed by three discourses. Close attention should be paid to the different understandings of quality, as they affect the provision of career guidance.
\end{abstract}

\section{INTRODUCTION $^{1}$}

Career guidance has been present in Norway in different forms and formats since the beginning of the 1900s (Kjærgård, 2012). Policy interest in assuring high quality in career guidance has increased since the beginning of 2000 (Norwegian Ministry of Education and Research, 2017; Haug et al., 2019). One rationale for high quality guidance is the rhetoric of a new, uncertain or liquid society (e.g. Bauman, 2006), and the implications of such a society for the individual and their career journey through life. Technological advances, changes in industrial structures, immigration and an aging population will affect the skills-need across the economy. Furthermore, most people will have to make many career decisions in the course of their lives. It is therefore argued that making good, well-informed career decisions is more important than ever before (Norwegian Ministry of Education and Research, 2017).

Career guidance can, according to the OECD (2004), help to support individuals' decision-making and career building. It has a societal impact on the effective functioning of the labour market, education system and social welfare system. A recent Norwegian governmental report (NOU, 2016, p. 7) argues that access to high-quality career guidance services is crucial in times of change and transition and has supported this through the development of a national quality framework for career guidance (Skills Norway, 2018; Haug et al., 2019). The main objective of this framework is to strengthen quality and professionalism in the field of career guidance as a whole, through a cross-sectoral and transversal tool for quality development and government. This framework is founded on four questions: (1) what defines good and ethical practice, (2) what competences do career practitioners need, (3) what should be the learning outcome of lifelong guidance, (4) how can we know what we do is high quality (Haug et al., 2019). 
This chapter is based on the empirical findings of my doctoral thesis (Haug, 2016, 2017) and the recent development towards a national quality framework for career guidance in Norway (Haug et al., 2019). The issue that is elaborated in this chapter is quality in career guidance in a single specific context (schools) and in one country (Norway). However, the findings presented may be relevant more widely across the Nordic countries and beyond.

\section{SCIENTIFIC UNDERPINNING AND RESEARCH DESIGN}

This chapter builds on the scientific concepts of critical realism, a meta-theory that states that the relationship between reality and the concepts that we use to describe this reality should be the focal point of research and theoretical development (Danermark, Ekström, Jakobsen, \& Karlsson, 2003). Critical realism claims that scientific work is to 'investigate and identify relationships and non-relationships, respectively, between what we experience, what actually happens, and the underlying mechanisms that produce the events in the world' (Bhaskar, 1978, p. 56).

Kempster and Parry (2014, p. 88) advocate a grounded theory approach guided by a critical realistic (CR) frame to gain this insight. Key elements of this approach include 'First, clarifying the subject matter in relation to CR ontological assumptions. Second, data collection emphasizing exploring lived experience through interviews. Third, analysing data based on abduction and retroduction. Retroduction implies a commitment to theoretical pluralism, at least at the outset of an investigation. Multiple theoretical lenses can be considered for what they tell us about the various and stratified influences that are affecting the things we observe'.

The structure of this chapter will follow the three steps of Kempster and Parry's approach (2014). Firstly, I will clarify the theoretical conceptualisations of quality in career guidance in general. Secondly, I will highlight the main findings of the data collected in the project. Thirdly, I will discuss the understanding of quality in career guidance in a school context through multiple theoretical lenses.

\section{CLARIFYING THE SUBJECT MATTER: QUALITY IN CAREER GUIDANCE}

Quality is a complex and contested concept. We need to pay attention to this complexity and take action accordingly to maximise quality outcomes in the development of career guidance.

Understanding quality in career guidance to be both contested and complex aligns with several authors. For example, Sultana (2018a), who states that 'If you scratch below the surface, we discover that we have different views about what 'quality' really is. This is likely to depend on who we are, our social background, the evaluative criteria we use, past experiences, and so on. Most importantly, different people have different expectations and standards' (p. 8). Sultana (2017, p. 10) continues by saying 'Language and terms - and of course theoretical orientations, policies and practices - therefore, reveal important tensions in the field'. 
Plant (2004, p. 142), with reference to Watt (1998), elaborates this further by pointing out that a focus on quality encompasses many agendas, meanings and justifications.

- political: that the service is justified

- funding: that the service is financially worthwhile

- client progress measurement: to determine implementation of planned objectives

- monitoring: to record what happens

- strategic planning: organisational development

- practice and policy development: assess good practice, bench-marking

Plant (2004) argues that because of these agendas and positions, the understanding of quality is closely related to the different stances in the overall aim of career guidance. A figure was developed in a recent European project (Hughes \& Carson, 2018) to exemplify the many career guidance aims possible in a school context (Figure 14.1).
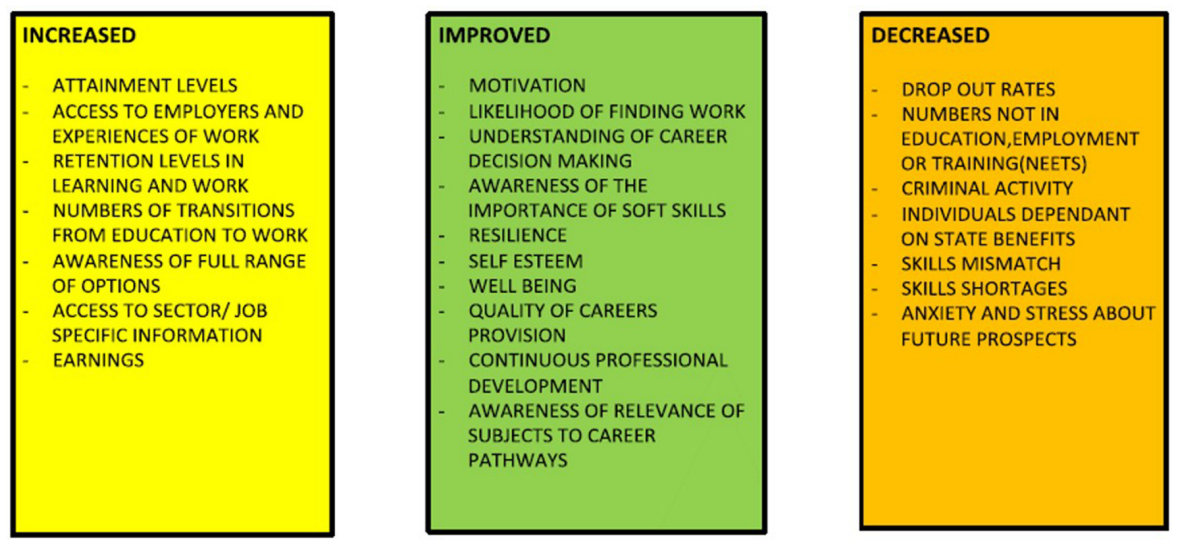

Figure 14.1. Examples of expected outputs for guidance in schools (from Hughes \& Carson, 2018, p. 16)

The many possible outputs shown in the figure range from concrete measurable outputs (i.e. lower dropout rates) to more abstract outputs that are difficult to measure (i.e. improved wellbeing). In this chapter, based on the scientific underpinning of critical realism which focuses on 'underlying mechanisms that produce the events in the world' (Bhaskar, 1978, p. 56), I primarily discuss the underlying patterns that can inform different positions, aims and understandings of good career guidance in a Norwegian school context.

Sultana $(2014,2018 \mathrm{a})$ has argued that it is possible to classify this diversity through a typology originally proposed by Habermas (1971). The typology consists of three inter-twining discourses that inform career guidance research, policy and 
practice. A technocratic discourse (on matching people to available occupations), a developmentalist or hermeneutic discourse (on personal growth and fulfilment), and an emancipatory discourse (on critiquing and transforming the world of work to improve social justice). The discourses 'serve as lenses that predispose us to consider specific social practices as 'problems', to articulate such 'problems' in particular ways, and to adopt one set of 'solutions' for them rather than another' (Sultana, 2018b, p. 101). Sultana (2018b) argues from this that the three discourses also inform the understandings of quality in guidance, and therefore can be useful tools in achieving a more flexible and multi-faceted understanding. The typology is, furthermore, used as the main theoretical conceptualisation in the discussion at the end of this chapter.

I will now present the main empirical findings from my earlier research (Haug, 2016, 2017) and use this as a basis for the analysis and interpretation of the underlying assumptions that inform the understanding of good career guidance. Through this, I move to step two of Kempster and Parry's critical realist grounded theory approach (2014).

\section{CAREER GUIDANCE QUALITY ARTICULATION IN THE NORWEGIAN SCHOOL CONTEXT}

Two sources and methodological approaches were used in this study to investigate the articulation of an understanding of quality in career guidance.

Semi-structured focus group interviews were held with users, practitioners and managers to investigate what I call 'local' voices (Haug, 2017). Understandings of quality were, therefore, collected from end users, providers and decision makers in regional schools in Norway. The participants were asked to talk about quality in career guidance in general and not assess a specific program or a service. This was an important feature of the interviews, the aim of the interviews therefore being to access their understanding of quality in career guidance rather than their retrospective evaluation of a service, which is a common approach in Norwegian school career guidance research (Haug et al., 2019b). My objective was to go deeper into the understandings of quality that inform retrospective evaluations.

The second source was a document study (Haug, 2016) of selected national steering documents that represent national perspectives on quality. Document selection included the curriculum for the compulsory subject Education Selection (Directorate of Education, 2015), see Røise (Chapter 18, this volume) for an in-depth description of this subject, legislation spanning from regulations to the National Education Act (1998) on career guidance in schools, and national competence recommendations for career guidance practitioners in schools (Directorate of Education, 2009). The main findings from these two types of sources and methodological approaches are presented below. This is followed by a discussion of the underlying assumptions that inform the articulation of quality in career guidance. 


\section{Main Results of the Focus Group Interviews}

The results (Haug, 2017) indicate that understandings of quality at the local level centre on three interrelated areas; the importance of practitioners' relational competence, a need to focus on the next career choice, and the benefits of including a range of actors and activities in career guidance provision. Interviewees, when asked to define quality in career guidance, state that practitioners' relational competence is the most important ingredient. One quote that defines this is the following:

Being good at talking with students underpins good guidance. Anyone can provide information on the educational and vocational systems ... Really communicating with youngsters is, however, different. It has something to do with credibility. Spending time with an adviser is nice, she understands us you know?

Another participant says about quality:

A meeting between student and counsellor that is in equilibrium. Where the student feels secure. Where there are more open questions than 'standard' answers. Where the student feels he or she is on a journey that will benefit them, that that they can grow.

The second most important ingredient was the need to focus on the next career choice. A quote that defines this was as follows:

The focus should be on making a good, sound upper secondary school choice decision. Guidance is then good and effective.

The third most important ingredient relates to the benefits of including a range of actors and activities in service provision. One quote defining this was as follows:

The combination of visits to companies and work in the classroom with the booklet (my future) works well. We, when working on the booklet, write down what we are good at. There has been no focus on how we can use these strengths. One day visits are also nice, because we learn more about the companies.

The quality of career guidance is therefore characterised by 'good' conversations with a counsellor, in which the purpose of the conversation is to make the student feel confident when they next have to make a decision. This is, however, nuanced by the third defining theme's emphasis on a range of actors, activities and arenas. This, in the interviews, primarily relates to the understanding that career choices must be seen in the context of 'something'.

The actors interviewed were convinced that teachers can contribute by drawing on their experiences from their own careers. Experience from life will be an important input for students when making their decisions. The informants were, however, concerned about the risk that teachers primarily have an academic education, and 
therefore do not have first-hand knowledge of other educational and vocational areas. They therefore point out the importance of cooperation with external actors, which they believe can have a positive impact on quality. This includes companies visiting schools to talk about their work and workplace and making their workplaces available for experience-based learning opportunities. Career exploration through work experience is emphasised as being beneficial to students and of giving them an experience which they can measure the options open to them against (Haug, 2017).

\section{Main Results from the Analysis of Selected National Steering Documents}

The trend towards considering the student as an active participant, with the power and authority to influence and be responsible for his or her own career-related actions, is an important feature of the steering documents. The following is taken from the Education Selection curriculum (Directorate of Education, 2015, p. 1):

The course is to help students gain skills in making career choices, based on the pupils' wishes and prerequisites.

This point of view is made explicit in the competence criteria for education and vocational counsellors (Directorate of Education, 2009, p. 1):

Can help pupils develop self-esteem and the ability to help themselves.

The aim of career guidance (Directorate of Education, 2015, pp. 3-4) is described as being that students:

... collect, analyse and use information about education and occupations in different ways in career planning; formulate own short-term and long-term career goals based on interests and opportunities; describe and know about different educational programs and give examples of the professions education programs can lead to.

Section 22-3 of the Education Act's (2006) regulations states that students are entitled to:

Updated information on education paths in Norway and other countries; updated information on occupational areas and the local, national and international labour market; training to find and navigate through information sources, use of guidance tools and information on application deadlines, admission conditions and funding schemes.

These objectives are reflected in the competence criteria for educational and vocational counsellors (Directorate of Education, 2009, p. 5), and include:

Possess a good knowledge of the Norwegian educational system and of the education systems of other countries; have a good knowledge of education opportunities in Norway and in other countries, including application 
deadlines, admission conditions, funding methods and required professional combinations, have a good knowledge of working life and the national and international labour market.

\section{DISCUSSION}

I will now discuss the underlying patterns that inform the articulation of good career guidance in the above paragraphs, using Sultana's (2014) three-discourse typology.

A major trend towards considering the student as an active citizen, with the power and authority to influence and be responsible for his or her career-related decisions, was my first observation of the underlying patterns. Previous research into practitioners' understandings of their role has also highlighted respect for students' autonomy. Buland, Mathiesen and Mordal (2014) write that:

Most counsellors are very conscious of their responsibility to facilitate a positive learning process for the student, to help the pupil to help him or herself, and to not make decisions on the student's behalf. Counsellors in discussions with students have often sought to encourage students to think for themselves and make their own decisions rather than the counsellor 'choosing for them'. (p. 189)

The emphasis on the importance of active citizenship aligns with the hermeneutic discourse in Sultana's typology (2014). The underlying understanding in the articulations of good guidance is, furthermore, close to Sultana's description of one who 'highlights human beings' interest in communication, social interaction, and interpretation - the intersubjective 'playfulness' in securing and extending possibilities of understanding oneself and others in the conduct of life' (p. 16). In the context of career guidance, Sultana states that 'The personal growth and fulfilment of the individual are considered to be paramount, with every effort being made to support the self-discovery and flourishing of capacities and aspirations' (Sultana, 2018b, p. 103).

Guichard (2001) elaborates further on the origin of this understanding, and explains the individual orientation in career guidance in Western industrialised countries as an ideological framework that recognises and appreciates the development of the self in open, flexible societies. The freedom to pursue one's own goals is an important value in societies that are based on such an ideology. Every individual is considered to be a responsible autonomous person, who is able to make independent choices. Selfreflection and self-construction are, therefore, important goals. Such an ideological framework and theoretical perspective on society and society's structures can be seen to be liquid.

A spokesperson for such an understanding of reality is Bauman (2006). He describes contemporary social structure as being a liquid modernity. He views today's society as being characterised by the resolution, decomposition and disassembly 
of the social forms, traditions and structures that previously restricted individual freedom of choice. According to Beck and Beck-Gernsheim (2002), such a social structure requires the following:

Individuals must be able to plan in the long run and adapt to the circumstances, they must organize and improvise, set goals, identify obstacles, find themselves in defeat and try new beginnings. They need initiative, stamina, flexibility and frustration tolerance. (p. 17)

Andrews (2011) associates this understanding of the aim of career guidance as being 'learning for a career'. He writes,

This targets the development of skills for planning and managing one's career. (p. 130)

Another important theoretical point of departure for an individualistic focus and grounding force in the articulation of good career guidance, is found in the personcentred approach associated with Carl Rogers (1961). The person-centred approach assumes that:

man by nature will develop or act in the most positive, constructive, creative, and pro-social direction possible under the given circumstances and conditions. (Sommerbeck, 2002, p. 2)

Rogers' (1961) starting point is that the best conditions for personal growth are provided where the student is considered to be the expert on their own life. The student should therefore play the leading role in his or her own decision process.

Savickas (2015) provides yet another theoretical lens. He argues that the objectives of career guidance are oriented towards adaptation (between individuals and occupational and vocational opportunities), competence development and meaning making. My interpretation is that the empirical findings of my investigation show a tendency towards seeing competence development as a primary objective.

The goal of developing competence can relate to both personal and social needs (Watts, 1999). The Norwegian Career Guidance Committee's statement calls for the political intention that career guidance should address the needs of both the individual and society (NOU, 2016, p. 7):

Socially, because the state has an interest in education and work guidance a well-informed population makes better and better-informed decisions. Personal, because guidance is focused on the individual and the individual's way through life. (p. 22)

Watts (1999), however, argues for a turn towards guidance being seen as a tool that society can use to ensure it has the future skilled workforce it requires. Bengtsson (2016) continues this argument by claiming that the increasing interest in career guidance can be largely explained by career guidance being linked to the so-called 
Lisbon Agreement (European Council, 2000, p. 3). Kjærgård (2012) argues that career guidance in our contemporary age can be seen to be a part of a competencebased discourse. This aligns with the technocratic discourse in Sultana's typology (2014), which Sultana refers to as one of the dominant discourses in career guidance. Here, "the main concern is to ensure a smoother relationship between supply and demand of skills for the benefit of the economy. The role of the career guidance consultant is to help individuals identify their skills profile and to match this as closely as possible with the (presumed) needs of the labour market' (Sultana, 2018b, p. 102).

The ideal of free choice as a prominent assumption is challenged by Gidden's (1998) perspective of a new social contract between the individual and society, based on the principle of 'no rights without obligations'. Recipients of social benefits must use them responsibly and give something back to society. This thinking is present in the empirical data. Formulations emphasise the central starting point of student wishes and needs, but also that the student must be able to see his or her choices in the light of the consequences these will have for society. I phrase this as an understanding of freedom within the framework of learning objectives. Society determines the competencies it believes it requires and individuals need to become a part of and contribute to this framework of requirement.

Kjærgård (Chapter 6, this volume) argues for the existence of a counter-discourse, particularly against the technocratic discourses evident in the current Norwegian field of career guidance. This argumentation builds on Sultana (2014) who states:

... both technocratic and hermeneutic approaches can easily lead to situations where individuals are seen independently from the social forces, economic structures, and cultural traditions that shape their lives in particular ways. While the former is more likely to encourage individuals to adapt and cope and fit in, and the latter to discursively project and construct a 'self' as part of an overall project of life design, both risk failing to place the issue of power - and hence of justice - as a central concern in their relationships with clients. (p. 19)

Roberts (2005) argues that the ideal of an individual's freedom of self-determination in the Western world has led to the exclusion from the current discourse, of empirical studies that show that class backgrounds, gender and ethnicity still have a significant impact on students' actual career choices.

Sultana's third discourse, the emancipatory, urges us to an increased awareness of these structural forces and through this be 'amenable to action that expands our possibilities for self-expression and self-fulfilment' (Hooley, Sultana, \& Thomsen, 2018, p. 32). The emancipatory is, in contrast to the previous two discourses, committed to questioning the status quo rather than to encouraging people to fit in (Sultana, 2018b).

Sentences such as 'Guidance should help to prevent social inequalities, prevent dropout and integrate ethnic minorities' (Educational Act, 200) are found in the 
articulations of good guidance presented in this chapter. However, the emancipatory discourse is the least prominent. That said, it is interesting to see that the preliminary version of the national lifelong quality framework for career guidance (Haug et al., 2019) carries an emancipatory 'touch'. The values that are outlined as underpinning this framework emphasise the idea that career guidance should help to promote equality and social justice. The most prominent example of this being found in the section on career competences. It is stated in a new definition suggested for the project, that career competence 'includes the insight that individuals are formed by their living conditions and actions, but that they can also influence and shape their own future and that of their community' (Haug et al., 2019, p. 45).

\section{CONCLUSION}

I began this chapter by stating that defining good career guidance is a complex and contested task. Different understandings of quality might oppose each other, and the judgement of quality is always characterised to some degree by uncertainty. Understandings of career guidance might change over time and differ between contexts. By comparing the definitions of good guidance found in Norway with the three-discourse typology of Sultana (2014), I have shown how the current situation in a Norwegian schools is primarily informed by a technocratic and hermeneutic discourse. The emancipatory discourse is present both in current articulations, and in particular in the suggested future direction set out in the newly proposed quality framework.

Hughes (2013) advocates a clear vision for future career guidance in schools in England. At a seminar at the 2018 IAEVG conference the experience of the Nordic countries was explored. The main challenge was said, in the seminar, to be the lack of a common language for good career guidance. I have advocated that this clarity or shared language should encompass a multifaceted, open and reflective approach to career planning for adolescents. Several discourses with different underlying assumptions are in play. If the multifaceted nature of quality is ignored there is a danger of unconsciously ending up either with only the voice of one position (e.g. policy or users) or at the other end of the scale, trying to encompass 'all' positions and ending up with a diffuse and imprecise approach. My approach coincides with the concept of positive relativism proposed by Sultana (2018a). Positive relativism:

recognises and respects differences, and is committed to the notion of 'reasonable accommodation', but in a context that reaches consensus around core civic values and communal norms that serve as the basis of collective life. (p. 9)

The goal has to be to provide a basis for mutual understanding of different positions on the quality of career guidance in planning, implementation and assessment. So moving from good to better. 


\section{CAREER GUIDANCE AND QUALITY IN NORWEGIAN SCHOOLS}

\section{NOTE}

1 All non-English quotes in the chapter are translated into English by the author and edited by a language specialist.

\section{REFERENCES}

Andrews, D. (2011). Careers education in schools. Stafford: Highflyers Publishing.

Bauman, Z. (2006). Liquid times: Living in an age of uncertainty. Cambridge: Polity Press.

Beck, U., \& Beck-Gernsheim, E. (2002). Individualization. Institutionalized individualism and its social and political consequences. London: Sage.

Bengtsson, A. (2016). Governance of career guidance. An enquiry into European policy (Thesis). Stockholm Universitet, Stockholm.

Bhaskar, R. (1978). A realist theory of science. Hassocks: Harvester Press.

Buland, T., Mathiesen, I. H., \& Mordal, S. (2014). E skjønne itj, a våkne opp kvar dag å vil bli nå nytt ce. Skolens rådgivning i Møre og Romsdal, Sør-Trøndelag og Nord-Trøndelag [I don't understand, I wake up every day and want to become something new]. Trondheim, Norway: NTNU. Program for livslang læring.

Danermark, B., Ekström, M., Jakobsen, L., \& Karlsson, J. C. (2003). Understanding society. Lund: Studentlitteratur.

Directorate of Education. (2009). Anbefalt formell kompetanse og kompetansekriterier for rådgivere [Recommended formal competence and competence criteria for coucellors]. Oslo, Norway: Utdanningsdirektoratet.

Directorate of Education. (2015). Lareplan i utdanningsvalg for ungdomstrinnet [Curriculum educational choice]. Oslo, Norway: Utdanningsdirektoratet. Retrieved from www.udir.no.

Educational Act. (1998). Lov 17. Juli 1998, nr. 61. Retrieved from www.lovdata.no.

European Council. (2000). Presidency conclusions. Brussels, Belgium: European Council. Retrieved from http://www.europarl.europa.eu/summits/lis1_en.htm

Giddens, A. (1998). The third way: The renewal of social democracy. Cambridge: Polity Press.

Guichard, J. (2001). A century of career education: Review and perspectives. International Journal of Educational and Vocational Guidance, 1, 155-176, doi:10.1023/A:1012207018303

Habermas, J. (1971). Knowledge and human interests. Boston, MA: Beacon Press.

Haug, E. H. (2016). Kvalitet i norske skolers karriereveiledning [Quality in Norwegian schools career guidance] (Doctoral thesis). Høgskolen i Innlandet.

Haug, E. H. (2017). Det er fint å være hos rådgiver, hun skjønner oss skjønner du. En empirisk studie av tema som anses som kjennetegn på kvalitet i skolens karriereveiledning [An empirical study of topics that are considered as characteristics of quality in the school's career guidance]. Nordisk tidsskrift $i$ veiledningspedagogikk, 2(1), 16-29. doi:10.15845/ntvp.v2i1.1161

Haug, E. H., Holm-Nordhagen, A., Thomsen, R., Schulstok, T., Engh, L. W., Gravås, T. F., Bakke, G. E., \& Gaarder, I. E. (2019). Nasjonalt kvalitetsrammeverk for karriereveiledning. Faglig forslag til områdene etikk, karrierekompetanse og kompetansestandarder [National Quality Framework for career guidance. Professional suggestion for ethics, career competence and competence standards]. Oslo, Norway: Kompetence Norge [Skills Norway]. Retrieved from https:/www.kompetansenorge. no/globalassets/karriere/rapport-nasjonalt-kvalitetsrammeverk-for-karriereveiledning.pdf

Haug, E. H., Plant, P., Valdimarsdóttir, S., Bergmo-Prvulovic, I., Vuorinen, R., Loven, A., \& Vilhjalmsdottir, G. (2019b). Nordic research on educational and vocational guidance: A systematic literature review of thematic features between 2003 and 2016. International Journal for Educational and Vocational Guidance, 19, 185-202. doi:10.1007/s10775-018-9375-4

Hooley, T., Sultana, R., \& Thomsen, R. (2018). The neoliberal challenge to career guidance - Mobilising research, policy and practice around social justice. In T. Hooley, R. G. Sultana, \& R. Thomsen (Eds.), Career guidance for social justice: Contesting neoliberalism (pp. 1-28). New York, NY: Routledge.

Hughes, D. (2013). The changing UK careers landscape: Tidal waves, turbulence and transformation. British Journal for Guidance and Counselling, 41, 226-239. doi:10.1080/03069885.2013.788131 
Hughes, D., \& Carson, T. (2018). The development of evidence-based practice in guidance services in schools. Report. The National Centre for Guidance in Education. Retrieved from https://www.ncge.ie/ ncge/DublinTCA

Kempster, S., \& Parry, K. W. (2014). Critical realism and grounded theory. In P. K Edwards, J. O’Mahoney, \& S. Vincent (Eds.), Studying organizations using critical realism (pp. 86-108). Oxford: Oxford University Press.

Kjærgård, R. (2012). Karriereveiledningens genealogi. Den suverene stats regulering av det frie utdannings- og yrkesvalg [Geneology of career guidance. The regulation of the free educational and vocational choice] (Thesis). Aarhus University, Aarhus, Denmark.

Norges offentlige utredninger (NOU) 2016:7. (2016). Norge i omstilling. Karriereveiledning for individ og samfunn [Career guidance for the individual and the society]. Oslo, Norway: Kunnskapsdepartementet.

Norwegian Ministry of Education and Research. (2017). Nasjonal kompetansepolitisk strategi [National skills strategy report]. Oslo, Norway: Regjeringen.

Organisation for Economic Co-operation and Development (OECD). (2004). Career guidance: A handbook for policy makers. Paris, France: OECD.

Plant, P. (2004). Quality in career guidance: Issues and methods. International Journal for Educational and Vocational Guidance, 4, 141-167. doi:10.1007/s10775-005-1023-0

Regulations related to the Educational Act. (2006). Forskrift 23. juni $2006 \mathrm{nr}$. 724. Retrieved from https://lovdata.no/dokument/SF/forskrift/2006-06-23-724

Roberts, K. (2005). Social classes, opportunity structures and career guidance. In B. A Irving \& B. Malik (Eds.), Critical reflections on career education and guidance: Promoting social justice within a global ecomony (pp. 130-143). London: Routledge.

Rogers, C. (1961). On becoming a person. Boston, MA: Hougton Mifflin Company.

Savickas, M. (2015). Career counseling paradigms: Guiding, developing, and designing. In J. P. Hartung, M. L. Savicas, \& W. Bruce (Eds.), APA handbook of career intervention (Vol. 1, pp. 129-142). Washington, DC: American Psychological Association.

Skills Norway. (2018). About the national quality framework for career guidance. Retrieved from https://www.kompetansenorge.no/Karriereveiledning/kvalitet-i-karriereveiledning/en-introduksjon/

Sommerbeck, L. (2002). Klienten er eksperten [The client as the expert]. Psykolognyt, 56(6).

Sultana, R. G. (2014). Rousseau's chains: Striving for greater social justice through emancipatory career guidance. Journal of the National Institute for Career Education and Counselling, 33(1), 15-23.

Sultana, R. G. (2017). Career guidance and livelihood planning across the mediterranean: Challenging transitions in South Europe and the MENA region (EMCER). Rotterdam, The Netherlands: Sense Publishers.

Sultana, R. G. (2018a). Enhancing the quality of career guidance in secondary schools. Handbook: MYFUTURE-project. Retrieved from https://myfutureproject.eu/resources/

Sultana, R. G. (2018b). Precarity, austerity and the social contract in a liquid world career guidance mediating the citizen and the state. In T. Hooley, R. Sultana, \& R. Thomsen (Eds.), Career guidance for social justice: Contesting neoliberalism (pp. 58-72). New York, NY: Routledge.

Watt, G. (1998). Supporting employability: Guides to good practice in employmnet counselling and guidance. Luxembourg: Office for Official Publications of the European Communities.

Retrieved from http://edz.bib.uni-mannheim.de/www-edz/pdf/ef/98/ef9834en.pdf

Watts, A. G. (1999). The economic and social benefits of guidance. Educational and Vocational Guidance Bulletin, 63. 